\title{
Anti-snake venom and analgesic activities of extracts and betulinic and oleanolic acids isolated from Parinari curatellifolia
}

\begin{tabular}{|c|c|}
\hline \multicolumn{2}{|c|}{ 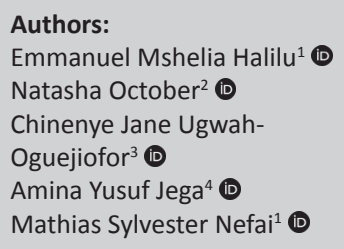 } \\
\hline \multicolumn{2}{|c|}{$\begin{array}{l}\text { Affiliations: } \\
{ }^{1} \text { Department of } \\
\text { Pharmacognosy and } \\
\text { Ethnomedicine, Usmanu } \\
\text { Danfodiyo University, } \\
\text { Sokoto, Nigeria }\end{array}$} \\
\hline \multicolumn{2}{|c|}{$\begin{array}{l}{ }^{2} \text { Department of Chemistry, } \\
\text { University of Pretoria, } \\
\text { Pretoria, South Africa }\end{array}$} \\
\hline \multicolumn{2}{|c|}{$\begin{array}{l}{ }^{3} \text { Department of } \\
\text { Pharmacology and } \\
\text { Toxicology, Usmanu } \\
\text { Danfodiyo University, Sokoto, } \\
\text { Nigeria }\end{array}$} \\
\hline \multicolumn{2}{|c|}{$\begin{array}{l}{ }^{4} \text { Department of } \\
\text { Pharmaceutical and } \\
\text { Medicinal Chemistry, } \\
\text { Usmanu Danfodiyo } \\
\text { University, Sokoto, Nigeria }\end{array}$} \\
\hline \multicolumn{2}{|c|}{$\begin{array}{l}\text { Corresponding author: } \\
\text { Emmanuel Mshelia Halilu, } \\
\text { emshelia2002@gmail.com }\end{array}$} \\
\hline \multicolumn{2}{|c|}{$\begin{array}{l}\text { Dates: } \\
\text { Received: } 08 \text { Oct. } 2019 \\
\text { Accepted: } 08 \text { Apr. } 2020 \\
\text { Published: } 29 \text { June } 2020\end{array}$} \\
\hline \multicolumn{2}{|l|}{ Read online: } \\
\hline 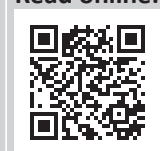 & $\begin{array}{l}\text { Scan this QR } \\
\text { code with your } \\
\text { smart phone or } \\
\text { mobile device } \\
\text { to read online. }\end{array}$ \\
\hline
\end{tabular}

Background: Parinari curatellifolia is used in Nigeria by traditional medicine practitioners (TMPs) for the treatment of snakebite and other conditions.

Aim: This study is aimed at evaluating the anti-snake venom (ASV) and analgesic activities of n-hexane, ethyl acetate and methanol extracts as well as that of betulinic and oleanolic acids.

Setting: The extracts and the isolates were subjected to acute toxicity studies, anti-snake venom and analgesic activities.

Methods: Acute toxicity studies for the extracts were performed according to Lorke's method whilst that of betulinic and oleanolic acids were performed according to Organization for Economic Co-operation Development 425 at the limit dose of $2000 \mathrm{mg} / \mathrm{kg}$ in mice. The ASV activity of the extracts and the betulinic and oleanolic acids were screened against Naja nigricollis venom phospholipases using the phospholipase-A2 acidimetric assay. The analgesic activity of ethyl acetate extract $(35 \mathrm{mg} / \mathrm{kg}, 70 \mathrm{mg} / \mathrm{kg}, 140 \mathrm{mg} / \mathrm{kg})$, betulinic acid $(1 \mathrm{mg} / \mathrm{kg}$, $5 \mathrm{mg} / \mathrm{kg}, 10 \mathrm{mg} / \mathrm{kg}$ ) and oleanolic acid $(1 \mathrm{mg} / \mathrm{kg}, 5 \mathrm{mg} / \mathrm{kg}, 10 \mathrm{mg} / \mathrm{kg})$ were evaluated using acetic acid-induced abdominal constrictions in mice.

Results: The $\mathrm{LD}_{50}$ of the methanol and ethyl acetate extracts were $113 \mathrm{mg} / \mathrm{kg}$ and $471.17 \mathrm{mg} / \mathrm{kg}$, respectively, whilst that of the betulinic and oleanolic acids were greater than $2000 \mathrm{mg} / \mathrm{kg}$. In the ASV study, the extracts inhibited the hydrolytic action of phospholipases with a percentage inhibition of $24.1 \%$ (n-hexane), $29.3 \%$ (ethyl acetate) and $20.7 \%$ (methanol), whilst the ASV (standard) caused $72.9 \%$ inhibition. On the other hand, the betulinic and oleanolic acids inhibited the hydrolytic action of phospholipases with a percentage inhibition of $35.6 \%$ and $31.4 \%$ respectively. For the analgesic evaluation, the ethyl acetate extract exhibited analgesic activity by producing a significant $(p<0.05)$ reduction in the number of writhes $(7.75 \pm 1.20$, $11.82 \pm 3.10$ and $14.98 \pm 2.72)$ at $140 \mathrm{mg} / \mathrm{kg}, 70 \mathrm{mg} / \mathrm{kg}$ and $35 \mathrm{mg} / \mathrm{kg}$, respectively. Betulinic acid at $10 \mathrm{mg} / \mathrm{kg}, 5 \mathrm{mg} / \mathrm{kg}$ and $1 \mathrm{mg} / \mathrm{kg}$ showed a mean number of writhes of $3.40 \pm 0.8$, $4.20 \pm 1.4$ and $5.60 \pm 2.1$, respectively. Oleanolic acid at $10 \mathrm{mg} / \mathrm{kg}$ and $5 \mathrm{mg} / \mathrm{kg}$ also showed $7.50 \pm 2.6$ and $6.40 \pm 1.8$ mean number of writhes.

Conclusion: This study has validated scientifically why P. curatellifolia is used traditionally in the treatment of snakebite, as the ethyl acetate extract and the isolated compounds moderately inhibited the hydrolytic action of phospholipase-A2. Also, betulinic and oleanolic acids exhibited analgesic activity in acetic acid-induced writhing in mice.

Keywords: Acute toxicity; analgesic; anti-snake venom; betulinic acid; oleanolic acid; Naja nigricollis; phospholipase-A2; Parinari curatellifolia.

\section{Introduction}

Most African countries are known worldwide to contain diverse varieties of venomous snake families, which include vipers, kraits and cobras (Kaushik et al. 2013). The most common snake families in Nigeria are the viperidae, elapidae, colubridae and actraspididae, with the viperidae accounting for about $66 \%$ of bites (Habib, Gebi \& Onyemelukwe 2001). The major species responsible for bites in north-eastern Nigeria is the Echis carinatus (carpet viper) (Abubakar et al. 2010; Habib et al. 2008). Others include Naja nigricollis (black-necked spitting cobra), Bitis arietans

How to cite this article: Halilu, M.E., October, N., Ugwah-Oguejiofor, C.J., Jega, A.Y. \& Nefai, M.S., 2020, 'Anti-snake venom and analgesic activities of extracts and betulinic and oleanolic acids isolated from Parinari curatellifolia', Journal of Medicinal Plants for Economic Development 4(1), a77. https://doi.org/10.4102/jomped.v4i1.77

Copyright: ( 2020 . The Authors. Licensee: AOSIS. This work is licensed under the Creative Commons Attribution License. 
(puff adder) and, to a lesser extent, Causus maculatus (night adder), Naja katiensis (Mali cobra), Naja haje (Egyptian cobra), Atractaspis microlepidota (small-scaled burrowing asp), Telescopus variegatus (variable cat or variable tiger snake) and several species of rat snake, sand snake and Lycophidion semicinctum (semi-annulated wolf snake) (Abubakar et al. 2010).

Naja nigricollis is a moderately sized snake with a distinct head. It can grow to a length of $1.2 \mathrm{~m}-2.2 \mathrm{~m}$. It has two large venom glands found on each side of the head, resulting in the shape of its head. The venom contains the enzyme phospholipase- $\mathrm{A}_{2}\left(\mathrm{PLA}_{2}\right)$ in large quantities. This enzyme catalyses the hydrolysis of fatty esters in the 2-position of 3-phospholipids to release fatty acids and lysophospholipid. The snake is predominantly black with a dull metallic sheen under the surface of the neck (Sani et al. 2018; Tamiya 1985) and tends to project venom from its fangs at a potential threat (Spawls \& Branch 1995). The spitting cobra is not usually aggressive, but when molested it will attack viciously and persistently (Tamiya 1985).

Snakebites are a serious public health concern that plagues many rural communities in Nigeria (Ekwere et al. 2010; Yusuf et al. 2015). The incidence of snakebites in Nigeria and the type of snake seem to vary according to the geographical zone, the occupational practices of the people and the season (Omogbai et al. 2002). There is no proper record of snakebites in Nigeria (Yusuf et al. 2015), but it has been estimated that the mortality rate ranges from 2 to 16 per 100000 each year (Theakston et al. 1995). The incidence of snakebites in people in the rural communities, where most of the people engage in agricultural, pastoral and other outdoor activities as a source of livelihood, is very high (Habib 2013; Kaushik et al. 2013). It has been reported by Habib et al. (2008) that the incidence of snakebites in Nigeria is about 497 per 100000 people per year with a $10 \%-20 \%$ mortality in bites left untreated. Apart from mortality, some snakebite victims survive but have permanent physical damage due to local tissue necrosis. The burden of human suffering caused by snakebite has been greatly underestimated, ignored and neglected for too long (Habib 2013). Snakebites cause death in about 50 000-60 000 people per year (Kaushik et al. 2013).

Snake venom contains several pharmacologically active peptides and proteins. The proteins are mostly metalloproteinases (enzymes). Snakevenom metalloproteinase induces haemorrhage, local myonecrosis, skin damage, inflammatory reaction and arthritis and is responsible for causing paralysis (Kaushik et al. 2013). The venom also contains toxic $\mathrm{PLA}_{2}$ with presynaptic neuromuscular blocking activity (Coelho 2004).

The treatment of snakebite is very costly (Kaushik et al. 2013) and therefore not affordable to poor people, especially those living in rural areas (Kadali, Kameswara \& Sandeep 2015; Kaushik et al. 2013). The main source snakebite treatment is the use of antisera (Sani et al. 2018). The use of snake venom antisera has adverse effects resulting from the presence of foreign proteins (Kaushik et al. 2013). These adverse effects (early and late hypersensitivity reactions) normally occur after one hour of administration (Kaushik et al. 2013). Therefore, there is need for the development of safer alternatives that are easily accessible, stable at room temperature and can neutralise a wide range of venom antigen with little or no side effects (Kaushik et al. 2013).

Many medicinal plants belonging to the Compositae, Leguminosae, Solanaceae and Apocynaceae families are well-documented in African material medica (Igoli, Tsenongo \& Tor-Anyiin 2011) and in other traditional medicine systems worldwide against snakebite. These plants contain bioactive principles like aristolochic acid, alkaloids, steroids, flavanoids, phenols, pterocarpanes, quinonoid xanthenes, resveratrol, glycoside and tannins which are effective antisnake venoms (ASVs). However, there is no comprehensive scientific validation of their efficacy (Kadali et al. 2015). Herbal preparations from these medicinal plants can serve as an alternative therapy in the management of snakebite, if developed. Studies on these herbal preparations have demonstrated neutralisation effects on viper, russell and cobra venoms (Molander 2012; Yusuf et al. 2019a, 2019b).

Pain disorders have been treated with natural products from the first documented evidence that dates back over 7000 years. To depict these claims, Papaver somniferum (opium poppy) and Salix alba (willow tree) are common examples. It was in the 19th century that morphine and aspirin were isolated from $P$. somniferum and Salix spp., respectively (McCurdy \& Scully 2005). Steroids (e.g. corticosteroids) and non-steroids (e.g. aspirin) are the drugs currently used as analgesics and in the management of inflammatory conditions. These drugs possess side and toxic effects which include renal failure, allergic reactions and hearing loss or they may increase the risk of haemorrhage by affecting platelet function (Anilkumar 2010; Sengupta, Sheorey \& Hinge 2012). On the other hand, there is a general perception that herbal medicines present little or no side effects and are safer (Sengupta et al. 2012). Plants from different families containing different chemical compounds and belonging to different chemical classes have been reported to demonstrate analgesic and anti-inflammatory activities (Anilkumar 2010; Kumar, Shete \& Akbar 2010; Sengupta et al. 2012).

Parinari curatellifolia (Planch. ex Benth.) belongs to the family chrysobalanaceae. The root and the stem bark of the plant are used in Nigeria and other African countries by traditional medicine practitioners (TMPs) for the treatment of snakebite, pain disorders and other diseases (Arnold \& Gulumian 1984; Kadali et al. 2015; Omale, Aguiyi \& Wannang 2010; Sidi et al. 2006; Ssegawa \& Kasenene 2007; Uys et al. 2002). Simeon et al. (2012) have reported the ASV (E. carinatus) activity of flavonoid fraction of the root bark extract of $P$. curatellifolia in mice. The flavonoid fraction at a dose of $237 \mathrm{mg} / \mathrm{kg}$ gave significant $(p<0.05)$ protection against the venom at $10 \mathrm{~min}$ and $30 \mathrm{~min}$ after pre-treatment with the 
venom. Halilu et al. (2008) have reported the presence of saponins, tannins, flavonoids, alkaloids, anthraquinones, steroids/triterpenoids and cardiac glycosides in the ethyl acetate fraction of the stem bark.

Betulinic acid is a pentacyclic lupane type of triterpene that is widely distributed in the plant kingdom (Ayatollahi et al. 2011; Rodrigues et al. 2010; Teh et al. 2010) and which has exhibited a variety of biological activity (Chatterjee et al. 2000). The isolation and characterisation of betulinic acid from P. curatellifolia have been reported by Halilu et al. (2013b). In addition, the evaluation of in-vitro antioxidant (DPPH [2, 2-diphenyl-1- picryl hydrazyl]) and in-vitro cytotoxic activity (XTT) of betulinic acid on the cervical cancer (HeLa) cell line have been reported (Halilu et al. 2013a), where betulinic acid demonstrated moderate to excellent antioxidant and cytotoxic activities. Oleanolic acid has been isolated in many plant species including Satureja mutica (Gohari et al. 2009), Lantana camara (Vyas \& Argal 2014), Uncaria macrophylla (Guangli et al. 2012), Grewia optiva (Uddin et al. 2011) and Borreria stachydea (Onoja \& Ndukwe 2013). The reported biological activities of oleanolic acid and its derivatives include anti-tumour or anticancer, antidiabetic, antimicrobial, hepatoprotective; and antihypertensive, antioxidant, anti-inflammatory and antiparasitic activities (Ayeleso, Matumba \& Mukwevho 2017). The oral acute toxicity study of oleanolic acid has been reported by Halilu et al. (2019). Despite the reported pharmacological activities of P. curatellifolia extracts and its isolated compound, the potential of P. curatellifolia ethyl acetate fraction and isolated compounds to treat pain and snakebite have not been investigated. Therefore, this study was designed to investigate the ASV activity of the solvent extracts, and analgesic activity of ethyl acetate extract and its isolated compounds (oleanolic and betulinic acids).

\section{Materials and methods}

\section{Collection, identification and authentication of the plant material}

The collection, identification and authentication of the plant material have been previously described by Halilu et al. (2013b). The leaves, flowers, fruits and stem bark of the plant were collected from Zaria, Kaduna State, Nigeria, in September 2011, and transported to the Herbarium Unit, Department of Biological Sciences, Faculty of Science, Ahmadu Bello University, Zaria, Nigeria, for identification and authentication by a taxonomist. Voucher number 903 was assigned to the herbarium specimen.

\section{Drying and preparation of the stem bark}

The drying and preparation of the stem bark have been previously described by Halilu et al. (2013b). The stem bark of the plant was shed dried for 1 week and powdered using a wooden pestle and mortar. The powder was stored in an airtight plastic container until required for use.

\section{Extraction of plant material}

The extraction of the powdered stem bark has been previously described by Halilu et al. (2013b) where the powdered plant material $(3 \mathrm{~kg}$ ) was successively extracted with $8 \mathrm{~L}$ each of n-hexane, ethyl acetate and methanol by cold maceration for $24 \mathrm{~h}$. The extracts were filtered and concentrated at reduced pressure using a rotary evaporator.

\section{Isolation and characterisation of betulinic and oleanolic acids}

The isolation and characterisation of betulinic and oleanolic acids from the ethyl acetate extract of $P$. curatellifolia stem bark have been described by Halilu et al. (2013b) and Halilu et al. (2019), respectively. The pentacyclic acids were isolated by gravity column chromatography using the gradient elution technique. The compounds were characterised on the basis of their infrared (IR), nuclear magnetic resonance (NMR) and mass spectrometry (MS) spectroscopy.

\section{Collection and preparation of snake venom}

The venom of $N$. nigricollis was collected by the milking procedure described by Macfarlane (1967) and reported by Yusuf et al. (2019b). The venom was pooled, freeze-dried and kept at $4{ }^{\circ} \mathrm{C}$ until required for use.

\section{Phospholipase- $A_{2}$ assay}

The acidimetric assay for PLA 2 enzymes, described by Tan and Tan (1988) and reported by Yusuf et al. (2019b), was followed in carrying out the evaluation. Equal volumes of the substrates containing calcium chloride $(18 \mathrm{mM})$, sodium deoxycholate $(8.1 \mathrm{mM})$ and egg yolk were mixed and stirred for $10 \mathrm{~min}$ to produce a homogenous mixture of egg yolk suspension. The $\mathrm{pH}$ of the suspension was adjusted to 8.0 by the addition of $1 \mathrm{M}$ sodium hydroxide. The snake venom (0.1 $\mathrm{mg} / \mathrm{mL}, 0.3 \mathrm{mg} / \mathrm{mL}$ and $0.3 \mathrm{mg} / \mathrm{mL}$ ) was added separately to $15 \mathrm{~mL}$ each of the above mixture to initiate the process of hydrolysis. Normal saline was used as a negative control. The $\mathrm{pH}$ of the suspension mixture and the snake venom was measured after 2 min using a $\mathrm{pH}$ meter. A decrease in $\mathrm{pH}$ was observed and noted. A decrease of $1.0 \mathrm{pH}$ unit corresponds to the $133 \mu$ moles of fatty acid released in the egg yolk mixture. Furthermore, enzymatic activity of $\mathrm{PLA}_{2}$ was calculated from the data obtained as $\mu$ moles of fatty acid released per minute. To test for the antivenin potentials of the extracts (n-hexane, ethyl acetate and methanol) and the isolates (betulinic and oleanolic acids), the snake venom $(0.1 \mathrm{mg})$ was pre-incubated with $0.5 \mathrm{mg} / \mathrm{mL}$ of the extracts and the isolates to neutralise PLA $_{2}$ hydrolytic action. The protections offered by the extracts and the isolates against phospholipases were measured and presented according to percentages as follows:

$\begin{aligned} & \text { Enzyme activity } \\ & (\mu \text { mole fatty acid/minutes })\end{aligned} \quad=\frac{\mu \text { mole of fatty acid released }}{\text { Time taken in minutes }}$

[Eqn 1] 
$\%$ enzyme activity $=\frac{\text { Enzyme activity of the test sample }}{\text { Enzyme activity of the venom }} \times 100$ $\%$ inhibition $=100-\%$ enzyme activity

[Eqn 2]

\section{Experimental animals}

Mice $(17 g-23 g)$ of either sex were obtained from the animal house of the Faculty of Pharmaceutical Sciences, Ahmadu Bello University, Zaria, Nigeria. The animals were acclimatised for 2 weeks before the commencement of the study. Standard commercial food and water were provided ad libitum for the animals. Housing conditions were maintained at $25^{\circ} \mathrm{C} \pm 2{ }^{\circ} \mathrm{C}$ at $12 \mathrm{~h}$ day/night cycles using an air conditioner. The study was approved by the Animal Research Ethics Committee, Usmanu Danfodiyo University, Sokoto (PTAC/PC(EA)/MT/12-19). The care and handling of the animals were done according to the established public health guidelines on Guide for Care and Use of Laboratory Animals (2011).

\section{Acute toxicity study of methanol and ethyl acetate extracts}

The acute toxicity studies were carried out on mice using a modified Lorke's method (1983). The mixture of male and female mice weighing $17 \mathrm{~g}-23 \mathrm{~g}$ was used. In the first phase of the experiment, nine mice were used. The nine mice were grouped into three groups of three mice each. The methanol extract was administered intraperitoneally (IP). To the first group, $1000 \mathrm{mg} / \mathrm{kg}$ of the methanol extract was administered; the second group received $100 \mathrm{mg} / \mathrm{kg}$; and the third group received $10 \mathrm{mg} / \mathrm{kg}$. From the result of the first phase of the experiment, the second phase of the experiment was carried out using four mice. To the first mouse, $160 \mathrm{mg} / \mathrm{kg}$ was administered; to the second mouse, $80 \mathrm{mg} / \mathrm{kg}$; to the third mouse, $40 \mathrm{mg} / \mathrm{kg}$; and to the fourth mouse, $20 \mathrm{mg} / \mathrm{kg}$. The animals were observed for $24 \mathrm{~h}$ after treatment. The above procedure was repeated using the ethyl acetate extract. The $\mathrm{LD}_{50}$ was determined from the highest dosage that killed the mice, and the lowest dosage that did not kill the mice. The median lethal dose $\left(\mathrm{LD}_{50}\right)$ was determined using Lorke's equation as follows:

$\mathrm{LD}_{50}=\sqrt{ }\left(\mathrm{D}_{\mathrm{o}} \times \mathrm{D}_{100}\right)$

[Eqn 3]

Where $\mathrm{D}_{\mathrm{o}}=$ highest dose for which the animal survives; and $\mathrm{D}_{100}=$ lowest dose for which the animal dies.

\section{Acute toxicity study of betulinic and oleanolic acids}

The oral acute toxicity study of the betulinic acid was carried out by the 'up-and-down' method in mice according to the Organisation for Economic Development (2008) guideline no. 425. A limited dose of betulinic acid (2000 mg/ $\mathrm{kg}$ ) was used for the study. Five female mice weighing $(17 \mathrm{~g}-23 \mathrm{~g})$ were used for the study. One mouse was picked at a time, weighed and dosed with the equivalent volume of the betulinic acid dissolved in a $20 \%$ tween $80+$ dimethyl sulphoxide (1:1) vehicle. The betulinic acid was administered orally using a gastric feeding tube and monitored according to OECD guideline no. 425 (2008), as reported by Halilu et al. (2019). The oral acute toxicity study of the oleanolic acid has been determined using the above method and the results have been reported previously by Halilu et al. (2019).

\section{Analgesic activity of ethyl acetate extract and betulinic and oleanolic acids}

\section{Acetic acid-induced abdominal constrictions (writhing)} in mice

The analgesic activity was determined according to the method described by Koster, Anderson and De Beer (1959). Forty adult albino mice were divided into eight groups consisting of five mice each. Groups 1, 2, 3, 5 and 6 were injected with $10 \mathrm{mg} / \mathrm{kg}, 5 \mathrm{mg} / \mathrm{kg}$ and $1 \mathrm{mg} / \mathrm{kg}$ IP of ethyl acetate extract, betulinic acid and oleanolic acid, respectively. Group 7 was injected with piroxicam $10 \mathrm{mg} / \mathrm{kg}$ (positive control) and group 8 was injected with $10 \mathrm{~mL} / \mathrm{kg}$ IP of normal saline (negative control). At the time interval of 30 min, each mouse was injected with $10 \mathrm{~mL} / \mathrm{kg}$ of an aqueous solution of acetic acid $(0.6 \%)$. The number of abdominal constrictions for each mouse was counted 5 min after the injection of acetic acid for a period of $10 \mathrm{~min}$. The percentage inhibition of abdominal constrictions was calculated using the following formula:

$$
\text { Inhibition }(\%)=\frac{\begin{array}{c}
\text { Mean no. of writhes (control) }- \text { mean no. } \\
\text { of writhes (test) }
\end{array}}{\text { Mean no. of writhes (control) }} \times 100
$$

\section{Statistical analysis}

All data are presented as a mean \pm standard error of mean (SEM) of six replicate readings. They were analysed using the GraphPad Prism version 6 software. One-way analysis of variance (ANOVA) was used to compare all groups, followed by student's $t$-test. Differences were considered significant at $p<0.05$.

\section{Ethical consideration}

The study was approved by the Animal Research Ethics Committee, Usmanu Danfodiyo University, Sokoto, PTAC/ PC(OA)/OT/007-18, 18 July 2018.

\section{Results}

\section{Anti-snake venom activity}

The effect of the extracts and betulinic and oleanolic acids on N. nigricollis $\mathrm{PLA}_{2}$ activity are presented in Table 1 . The ethyl acetate extract showed the highest enzyme inhibition of 29.3\%. The betulinic and oleanolic acids showed enzyme inhibitions of $35.6 \%$ and $31.4 \%$, respectively. 


\section{Acute toxicity study of methanol extract, ethyl acetate extract and betulinic acid}

The results of the acute toxicity of the crude methanol extract and the ethyl acetate fraction are presented in

TABLE 1: Effect of extracts and betulinic and oleanolic acids on Naja nigricollis phospholipase- $A_{2}$ activity.

\begin{tabular}{lcccc}
\hline Sample & $\begin{array}{c}\text { Fatty acid release } \\
(\boldsymbol{\mu} \text { mole/min) }\end{array}$ & $\begin{array}{c}\text { Enzyme activity } \\
(\mu \text { mole/FA/min) }\end{array}$ & $\begin{array}{c}\text { Enzyme } \\
\text { activity (\%) }\end{array}$ & $\begin{array}{c}\text { Enzyme } \\
\text { inhibition (\%) }\end{array}$ \\
\hline n-Hexane & 140.98 & 5.42 & 75.9 & 24.1 \\
Ethyl acetate & 126.35 & 5.05 & 70.7 & 29.3 \\
Methanol & 152.95 & 5.66 & 79.3 & 20.7 \\
Betulinic acid & 107.7 & 4.60 & 64.4 & 35.6 \\
Oleanolic acid & 113.1 & 4.90 & 68.6 & 31.4 \\
ASV (standard) & - & 0.93 & 27.1 & 72.9 \\
Venom (control) & 121.0 & 7.14 & 100.0 & 0.0 \\
\hline
\end{tabular}

ASV, anti-snake venom.

TABLE 2: Acute toxicity of ethyl acetate extract.

\begin{tabular}{lcc}
\hline Dose & Number of mice & Mortality \\
\hline Phase 1 dose $(\mathrm{mg} / \mathrm{kg})$ & 3 & \\
1000 & 3 & $3 / 3$ \\
100 & 3 & $0 / 3$ \\
10 & & $0 / 3$ \\
Phase 2 dose $(\mathrm{mg} / \mathrm{kg})$ & 1 & \\
600 & 1 & $1 / 1$ \\
370 & 1 & $0 / 1$ \\
225 & 1 & $0 / 1$ \\
140 & 1 & $0 / 1$ \\
\hline
\end{tabular}

TABLE 3: Acute toxicity of methanol extract.

\begin{tabular}{lcc}
\hline Dose & Number of mice & Mortality \\
\hline Phase 1 dose $(\mathrm{mg} / \mathrm{kg})$ & 3 & \\
1000 & 3 & $3 / 3$ \\
100 & 3 & $2 / 3$ \\
10 & & $0 / 3$ \\
Phase 2 dose $(\mathrm{mg} / \mathrm{kg})$ & 1 & \\
160 & 1 & $1 / 1$ \\
80 & 1 & $0 / 1$ \\
40 & 1 & $0 / 1$ \\
20 & 1 & $0 / 1$ \\
\hline
\end{tabular}

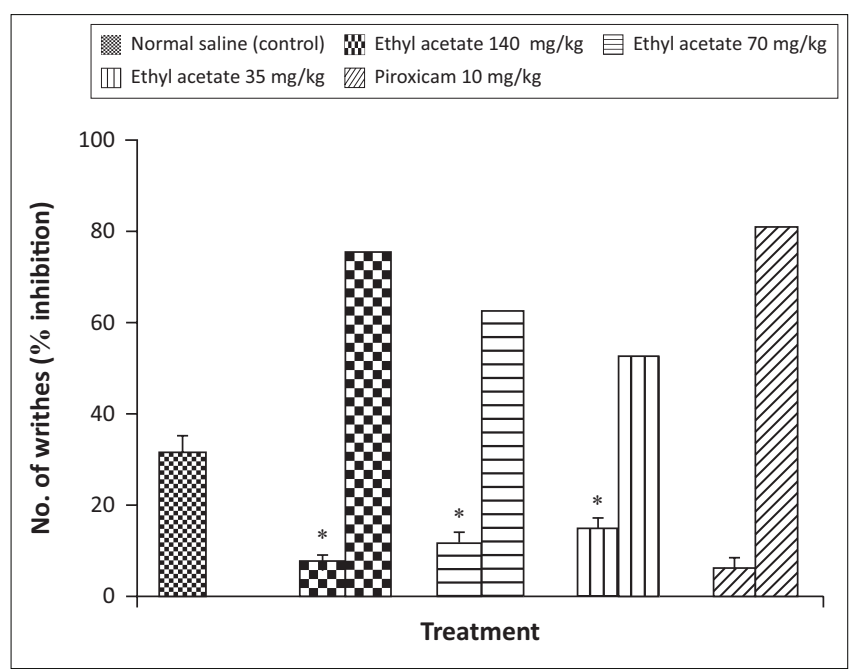

Note: Values represent mean number of writhes \pm SEM and (\% inhibition); $n=6$.

$*, p<0.05$ represents statistical significance when compared with normal saline (ANOVA, student's $t$-test).

FIGURE 1: Effect of ethyl acetate extract on acetic acid-induced writhing in mice.
Tables 2 and 3 . The $\mathrm{LD}_{50}$ of the crude methanol extract was calculated to be $113 \mathrm{mg} / \mathrm{kg}$, whilst that of the ethyl acetate fraction was found to be $471.17 \mathrm{mg} / \mathrm{kg}$. There was no mortality or any sign of toxicity observed at the administration of $2000 \mathrm{mg} / \mathrm{kg}$ of betulinic acid. Therefore, the $\mathrm{LD}_{50}$ of betulinic acid is greater than $2000 \mathrm{mg} / \mathrm{kg}$ (limit dose $\mathrm{PO}$ ). Also, the $\mathrm{LD}_{50}$ of the oleanolic acid was found to be greater than $2000 \mathrm{mg} / \mathrm{kg}$, as previously identified by Halilu et al. (2019).

\section{Analgesic study}

The effects of the ethyl acetate extract and betulinic and oleanolic acids on acetic acid-induced writhing in mice are presented in Figures 1, 2 and 3.

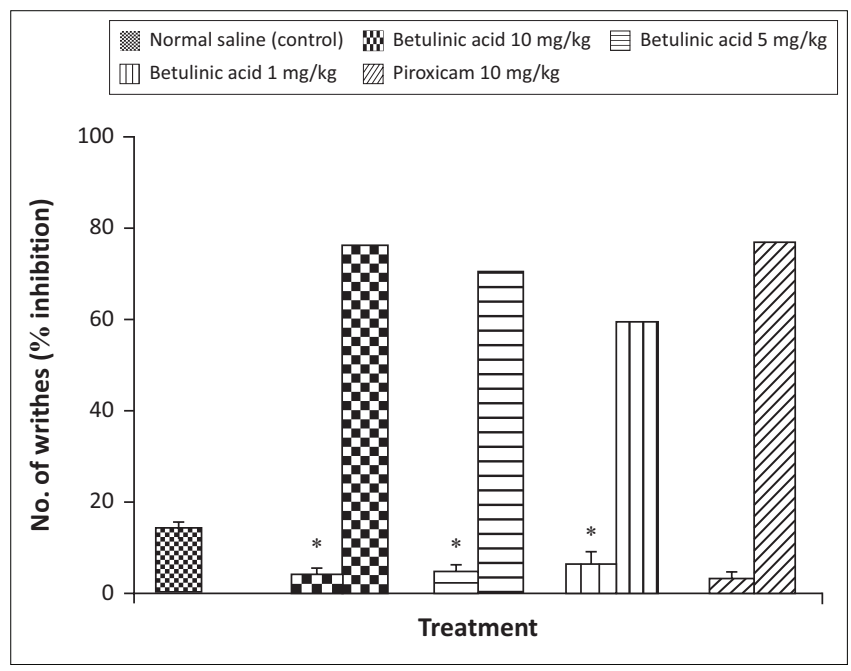

Note: Values represent mean number of writhes \pm SEM and ( $\%$ inhibition); $n=6$. $*, p<0.05$ represents statistical significance when compared with normal saline (ANOVA, student's $t$-test)

FIGURE 2: Effect of betulinic acid on acetic acid-induced writhing in mice.

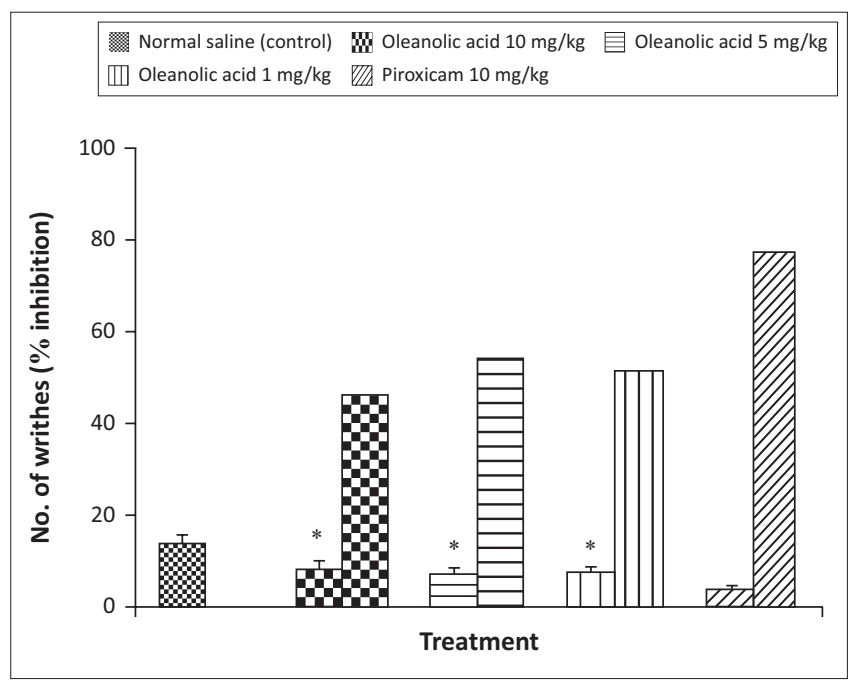

Note: Values represent mean number of writhes \pm SEM and ( $\%$ inhibition); $n=6$.

$*, p<0.05$ represents statistical significance when compared with normal saline (ANOVA, student's $t$-test).

FIGURE 3: Effect of oleanolic acid on acetic acid-induced writhing in mice. 


\section{Discussion}

Phospholipase- $\mathrm{A}_{2}$ is an enzyme present in large quantities in snake venoms which catalyse the hydrolysis of fatty esters in the 2-position of 3-phospholipids to release fatty acids and lysophospholipid. The fatty acid formed may act as either a second messenger or a precursor of eicosanoids

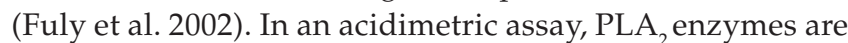
hydrolysed and free fatty acids released in the presence of sodium deoxycholate. Naja nigricollis venom liberates free fatty acids which is measured according to a decrease in the $\mathrm{pH}$ of egg yolk suspension. In this study, the venom $(0.3 \mathrm{mg} / \mathrm{mL})$ liberated $121.0 \mu$ mole of free fatty acids. The n-hexane and ethyl acetate and methanol extracts neutralised the phospholipases activity of $N$. nigricollis. The ethyl acetate extract inhibited the hydrolytic action of phospholipases and produced the highest percentage inhibition - greater than the n-hexane and methanol extracts. These extracts were found to be effective in neutralising the poisonous effect of PLA. The effectiveness of these extracts may be the result of the presence of the polyphenols (flavonoids and tannins), steroids/ triterpenoids and glycosides (Sani et al. 2018; Yusuf et al. $2019 a, 2019 b)$. The mode of action of the extracts against the $N$. nigricollis venom may be the result of the ability of the

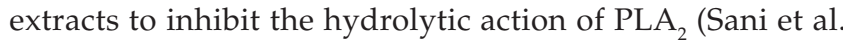
2018) In addition, betulinic and oleanolic acids also inhibited the hydrolytic action of phospholipases and were found to be effective in combating the poisonous effect of $\mathrm{PLA}_{2}$. Accordingly, by inhibiting the myotoxic effect induced by $\mathrm{PLA}_{2}$ present in the snake venom, a therapeutic potential of these fractions and isolates against necrosis in snakebite victims is achieved.

The $\mathrm{LD}_{50}$ of the methanol and ethyl acetate extracts were $113 \mathrm{mg} / \mathrm{kg}$ (IP) and $471.17 \mathrm{mg} / \mathrm{kg}$ (IP), respectively. Also, the $\mathrm{LD}_{50}$ of the betulinic acid and the oleanolic acid was greater than $2000 \mathrm{mg} / \mathrm{kg}$ (PO) as the animals survived at this dose of $2000 \mathrm{mg} / \mathrm{kg}$. The result of the acute toxicity showed a decrease in toxicity from the crude methanol extract through the ethyl acetate fraction and from the betulinic and oleanolic acids. Previous studies have shown that the $\mathrm{LD}_{50}$ of oleanolic acid is greater than $2000 \mathrm{mg} / \mathrm{kg}$ (Halilu et al. 2019) and this is in agreement with the result of the current study.

The effects of ethyl acetate fraction and betulinic and oleanolic acid fractions on peripheral nociception were determined, using the model of acetic acid-induced abdominal constrictions in mice, which is often used to assess both central and peripheral analgesia (Fukawa et al. 1980; Gene et al. 1998). The acetic acid causes an increase in peritoneal fluids of prostaglandin E2 and prostaglandin F2 $\alpha$ as a result of abdominal contractions, dorsoabdominal muscle twisting and sensitisation of peripheral chemosensitive nociceptors (Dirig et al. 1998), leading to the development of pain (Bley et al. 1998). In this study, betulinic and oleanolic acids exhibited significant $(p<0.05)$ analgesic activity in acetic acid-induced writhing in mice, indicating that they may possesses both central and peripherally mediated analgesic activity. Betulinic acid produced a strong analgesic effect on the acetic acid-induced writhing in the same order of magnitude as that observed after piroxicam administration at $10 \mathrm{mg} / \mathrm{kg}$, and there was a remarkable reduction of activity at $5 \mathrm{mg} / \mathrm{kg}$ and $1 \mathrm{mg} / \mathrm{kg}$. The observed trend indicates that the activity is dose-dependent. The oleanolic acid, on the other hand, exhibited its highest percentage inhibition at $5 \mathrm{mg} / \mathrm{kg}$ and the activity decreased as the dose was increased to $10 \mathrm{mg} / \mathrm{kg}$. The observed phenomenon may be the result of the fact that active phytochemicals, present in the plant extract, saturated the available receptors for the response (or activity). The mechanism of action is thought to involve, in part, local peritoneal receptors (Bentley, Newton \& Starr 1983); the isolates may have interfered with these peritoneal receptors to bring about analgesia (Musa et al. 2009).

\section{Conclusion}

The study showed that the extracts and the betulinic and the oleanolic acids inhibited the hydrolytic action of $\mathrm{PLA}_{2}$ present in $N$. nigricollis venom. A decrease in toxicity from the methanol and ethyl acetate extracts, and the isolates (betulinic and oleanolic acids) were observed. Both the betulinic and oleanolic acids exhibited significant analgesic activity in the acetic acid-induced writhing in mice. The betulinic acid showed a dose-dependent response.

\section{Acknowledgements}

The authors express their sincere appreciation to technologists in the Departments of Pharmacognosy and Ethnomedicine (Aliyu: for assistance in the extraction and phytochemical screening); Pharmacology and Toxicology (Abdullahi: for assistance in the determination of acute toxicity); and Pharmaceutical and Medicinal Chemistry (Hamza: for assistance in the determination of anti-snake venom activity).

\section{Competing interests}

No potential conflicts of interest were reported by the authors.

\section{Author's contributions}

H.E.M. was responsible for the isolation of compounds and the drafting of the manuscript. N.O. was responsible for isolation and characterisation. C.J.U.-O. was responsible for the acute toxicity study, analgesic study and statistical analyses. A.Y.J. conducted the anti-snake venom activity determination. M.S.N. collected the plant samples and proofread the manuscript.

\section{Funding information}

This research received no specific grant from any funding agency in the public, commercial or not-for-profit sectors. 


\section{Data availability statement}

Data sharing is not applicable to this article as no new data were created or analysed in this study.

\section{Disclaimer}

The views and opinions expressed in this article are those of the authors and do not necessarily reflect the official policy or position of any affiliated agency of the authors.

\section{References}

Abubakar, S.B., Habib, A.G., Abubakar, I.S., Larnyang, S., Durfa, N., Nasidi, A. et al 2010, 'Factors affecting snakebite mortality in north-eastern Nigeria', Royal Society for Tropical Medicine and Hygiene 10, 10-16.

Anilkumar, M., 2010, 'Ethnomedicinal plants as anti-inflammatory and analgesic agents', in D. Chattopadhyay (ed.), Ethnomedicine: A source of complementary therapeutics, pp. 267-293, Research Signpost, Kerala.

Arnold, H.J. \& Gulumian, M.J., 1984, 'Pharmacopoeia of traditional medicine in venda', Journal of Ethnopharmacology 12(1), 35-74. https://doi.org/10.1016/ 0378-8741(84)90086-2

Ayatollahi, A.M., Ghanadian, M., Afsharypour, S., Abdella, O.M., Mirzai, M. \& Askari, G., 2011, 'Pentacyclic triterpenes in Euphorbia microsciadia with thei T-cell proliferation activity', Iranian Journal of Pharmaceutical Research 10(2), 287-294.

Ayeleso, T.B., Matumba, M.G. \& Mukwevho, E., 2017, 'Oleanolic acid and its derivatives: Biological activities and therapeutic potential in chronic diseases', Molecules 22(11), 1915. https://doi.org/10.3390/molecules22111915

Bentley, G.A., Newton, S.H. \& Starr, J., 1983, 'Studies on the antinociceptive action of $\alpha$-agonist drugs and their interaction with opioid mechanisms', British Journa of Pharmacology 79(1), 125-134. https://doi.org/10.1111/j.1476-5381.1983. tb10504.x

Bley, K.R., Hunter, J.C., Eglen, R.M. \& Smith, J.A., 1998, 'The Role of IP prostanoid receptors in inflammatory pain', Trends in Pharmacological Science 19(4), 141-147. https://doi.org/10.1016/s0165-6147(98)01185-7. PMID: 9612089.

Chatterjee, P., Kouzi, S.A., Pezzuto, J.M. \& Hamann, M.T., 2000, 'Biotransformation of the antimelanoma agent betulinic acid by Bacillus megaterium ATCC $13368^{\prime}$ Applied and Environmental Microbiology 66(9), 3850-3855. https://doi. Applied and Environmental Microbio
org/10.1128/AEM.66.9.3850-3855.2000

Coelho, A.L.J., De Freitas, M.S., Mariano-Oliveira, A., Rapozo, D.C.M., Pinto, L.F.R. \& Niewiarowski, S. et al., 'RGD- and MLD-disintegrins, jarastatin and $\mathrm{EC}_{3}$, activate integrin-mediated signaling modulating the human neutrophils chemotaxis, apoptosis and IL-8 gene expression', Experimental Cell Research 292(2), 371-384. https://doi.org/10.1016/j.yexcr.2003.09.013

Dirig, D.M., Isakson, P.C. \& Yaksh, T.L. 1998, 'Effect of COX-1 and COX-2 inhibition on induction and maintenance of carrageenan-evoked thermal hyperalgesia in rats', Journal of Pharmacology and Experimental Therapeutics, 285(3), 1031-1038

Ekwere, E., Ede, S., McNeil, R. \& Aguiyi, J., 2010, 'Prevalence of snakebites in Taraba and Plateau states of Nigeria', Journal of Pharmacy \& Bioresources 7(1), 26-36. https://doi.org/10.4314/jpb.v7i1.67745

Engelmann, W.-E., 1981, Snakes: Biology, behaviour and relationship to man, p. 71 Leipzig Publishing, Leipzig.

Fukawa, K., Kawano, O., Hibi, M., Misaki, M., Ohba, S. \& Hatanaka, Y., 1980, 'A method for evaluating analgesic agents in rats', Journal of Pharmacological Methods, 4, 251-259.

Fuly, A.L., De Miranda, A.L.P., Zingali, R.B. \& Guimarās, J.A., 2002, 'Purification and characterization of a phospholipase A2 isoenzyme isolated from Lachesis muta snake venom', Biochemical Pharmacology 63(9), 1589-1597. https://doi.org/ 10.1016/S0006-2952(02)00873-0

Gené, R.M., Segura, L., Adzet, T., Marin, E. \& Inglesias, J., 1998, 'Heterotheca inuloides: Anti-inflammatory and analgesic effect', Journal of Ethnopharmacology 60(2), 157-162. https://doi.org/10.1016/S0378-8741(97)00155-4

Gohari, A.R., Saeidnia, S., Hadjiakhoondi, A., Abdoullahi, M. \& Nezafati, M., 2009, 'Isolation and quantificative analysis of oleanolic acid from Satureja mutica. Fisch. \& C. A. Mey', Journal of Medicinal Plants 8(suppl. 5), 65-69.

Guangli, S., Xiaopo, Z., Xudong, X., Junshan, Y., Mingliang, Z. \& Jingquan, Y., 2012, 'A new triterpene from the plant of Uncaria macrophylla', Molecules17(1), 504-510. https://doi.org/10.3390/molecules17010504

Guide for the Care and use of Laboratory Animals, 2011, National research council of the national academies, 8th edn., pp. 12-13, The National Academies Press, Washington DC.

Habib, A.G., Abubakar, S.B., Abubakar, I.S., Larnyang, S., Durfa, N., Nasidi, A., et al., 2008, 'Envenoming after carpet viper (Echis ocellatus) bite during pregnancy: Timely use of effective antivenom improves maternal and foetal outcomes', Tropical Medicine and International Health 13(9), 1172-1179.

Habib, A.G., Gebi, U.I. \& Onyemelukwe, G.C., 2001, 'Snake bite in Nigeria', African Journal of Medicine and Medical Science 30(3), 171-175.

Habib, G.A., 2013, 'Public health aspects of snakebite care in West Africa: Perspectives from Nigeria', Journal of Venomous Animals and Toxins including Tropical Diseases 19, 27. https://doi.org/10.1186/1678-9199-19-27
Halilu, M.E., Akpulu, I.K., Agunu, A., Ahmed, A. \& Abdurahman, E.M., 2008, 'Phytochemical and antibacterial evaluation of Parinari curatetellifolia Planch ex 'Benth (Chrysobalanaceae)', Nigerian Journal of Basic and Applied Sciences 16(2), Benth (Chrys 285.

Halilu, M.E., October, N., Balogun, M., Lall, N. \& Abubakar, M.S., 2013a, 'Studies of in vitro antioxidant and cytotoxic activities of extracts and isolated compounds from Parinari curatellifolia (Chrysobalanaceae)', Journal of Natural Sciences Research 3(13), 149-154.

Halilu, M.E., October, N., Balogun, M., Musa, K.Y. \& Abubakar, M.S., 2013b, 'Isolation and characterization of triterpenes from petroleum ether and ethyl acetate extracts of stem bark of Parinaricuratellifolia Planch ex. Benth (Chrysobalanaceae)', Chemistry and Materials Research 3(9), 100-107.

Halilu, M.E., Ugwah-Oguejiofor, C.J., October, N. \& Abubakar, K., 2019, 'Isolation of oleanolic acid from Parinari curatellifolia (Planch ex. Benth) stem bark and evaluation of its anticonvulsant and sedative activities in rodents', Tropical Journal of Natural Product Research 3(1), 17-21. https://doi.org/10.26538/tjnpr/v3i1.4

Igoli, J.O., Tsenongo, S.N. \& Tor-Anyiin, T.A., 2011, 'A survey of anti-venomous, toxic and other plants used in some parts of Tivland, Nigeria', International Journal of Medicinal and Aromatic Plants 1(3), 240-244.

Kadali, V.N., Kameswara, R.K. \& Sandeep, B.V., 2015, 'Medicinal plants with anti-snake venom property: A review', The Pharma Innovation Journal 4(7), 11-15.

Kaushik, A.K., Ambesajir, A., Kaushik, J.J. \& Girmay, B., 2013, 'Snake venom neutralization effects of African medicinal plants \& their impact on snakebites: A review', Asian Journal of Biomedical and Pharmaceutical Sciences 3(24), 1-6.

Koster, R., Anderson, M. \& De Beer, E.J., 1959, 'Acetic acid for analgesic screening', Federation Proceeds 18, 412-416.

Kumar, M., Shete, A. \& Akbar, Z., 2010, 'A review on analgesic: From natural sources', International Journal of Pharmaceutical \& Biological Archives 1(2), 95-100.

Macfarlane, R.G., 1967, 'Russell's viper's venoms 1934-64', British Journal of Haematology 13(s1), 437-451. https://doi.org/10.1111/j.1365-2141.1967. tb00754.x

McCurdy, C.R. \& Scully, S.S., 2005, 'Analgesic substances derived from natural products (natureceuticals)', Life Science 78(5), 476-484.

Molander, M., Saslis-Lagoudakis, C.H, Jäger, A.K. \& Rønsted. N., 2012, 'Cross-cultural comparison of medicinal floras used against snakebites', Journal of Ethnopharmacology,139(3), 863-72

Musa, A.M., Aliyu, A.B., Yaro, A.H., Magaji, M.G., Hassan, H.S. \& Abdullahi, M.I. 2009, 'Preliminary phytochemical, analgesic and anti-inflammatory studies of the methanol extract of Anisopus mannii (N.E.Br) (Asclepiadaceae) in rodents', African Journal of Pharmacy and harmacology, 3(8), 374-378, viewed August 2009, from http://www.academicjournals.org/ajpp

Omale, S., Aguiyi, J.C. \& Wannang, N.N., 2010, 'Screening for antisnake venom activities of the ethanolic extracts of the stem back of Parinari curatellifolia (Rosaceae) in mice after challenge with raw venom of Naja nigricollis', African Journal of Bioscience 3(1), 2-3.

Omogbai, E.K.I., Zuleikha, A.M.N., Imhafidon, M.A., Anwakang, A.I., Ojo, D.O. \& Nwako, C.N., 2002, 'Snake bites in Nigeria: A study of the prevalence and treatment in Benin City', Tropical Journal of Pharmaceutical Research 1(1), 39-44.

Onoja, E. \& Ndukwe, I.G., 2013, 'Isolation of oleanolic acid from chloroform extract of Borreria stachydea (DC)', Journal of Natural Product Plant Resources 3(2), $57-60$

Organization for Economic Co-operation Development (OECD), 1998, 'Principles of Good Laboratory Practice', in hand book of Good Laboratory Practice (GLP) TDR, PRD/GLP/revised Eidition, OECD Environment Directorate, Paris, Fance, http:// www.oecd.org.

Pateh, U.U., Sule, I.M., Iliya, I., Haruna, A.K., Yaro, A.H., Ambi, A.A. \& Musa, A., 2011 'Analgesic and anti-inflammatory activities of the methanolic extract of the rhizomes of Stylochiton lancifolius Pyer and Kotchy (Araceae) in rodents', Journal of Medicinal Plants Research 5(21), 5203-5207.

Rodrigues, F.E.A., Lima, J.Q., De Oliveira, M.D.C.F., Vasconcelos, J.N., Santiago, G.M.P., Mafezoli, J., et al., 2010, 'Diterpene and other constituents from Stemodia maritima (Scrophulariaceae)', Journal of the Brazilian Chemical Society 21(8), S1-S23.

Sani, I., Umar, R.A., Hassan, S.W. \& Faruq, U.Z., 2018, 'Antisnake venoms and their mechanisms of action: A review', Saudi Journal of Medical and Pharmaceutical Sciences 4(5), 512-520.

Sengupta, R., Sheorey, S.D. \& Hinge, M.A., 2012, 'Analgesic and anti-inflammatory plants: An updated review', International Journal of Pharmaceutical Sciences Review and Research 12(2), 114-119.

Sidi, S., Dominic, G., Charlotte, R. \& Moctar, S. 2006, Seed Leaflet No.110, February 2006, Parinari curatellifolia Planch. ex Benth. Millenium seed bank project, KEW's Phytotrade Africa, Forest and landscape, DK-2970 Hørsholm, Denmark, viewed 12 November 2012, from www.SL.kvl.dk

Simeon, O., Asa, A., Kennedy, I.A. \& Mriose, V.I., 2012, 'Anti-snake venom activity of flavonoids from the root bark of parinari curatellifolia in mice', International Journal of Pharmaceutical Research 4, 55-58.

Spawls, S. \& Branch, B., 1995, Dangerous snakes of Africa, p. 91, Blandford Press, London.

Ssegawa, P. \& Kasenene, J.M., 2007, 'Medicinal plant diversity and uses in the Sango bay area, Southern Uganda', Journal of Ethnopharmacology 113, 521-540.

Tamiya, N., 1985, 'A comparison of amino acid sequences of neurotoxins and phospholipase of some Australian elapid snakes with those of other proteroglyphous snakes', in G. Grigg, R. Shine \& H. Ehmann (eds.), Biology of proteroglyphous snakes', in G. Grigg, R. Shine \& H. Ehmann (eds.), Biology of
Australasian frogs and reptiles, pp. 209-219, Royal Zoological Society of New Australasian frogs and reptiles, pp. 209-219, Royal Zool
South Wales, Australia. Surrey and Sons, Chipping Norton. 
Tan, N.H. \& Tan, C.S., 1988, 'Acidimetric assay of phospholipase A using egg yolk suspension as substrate', Analytical Biochemistry 170(2), 282-288.

Teh, S.S., Ee, G.C.L., Rahmani, M., Sim, W.C., Mah, S.H. \& Teo, S.H., 2010, 'Two new pyranoxanthones from Mesua beccariana (Guttiferae)', Molecules 15(10), 6733-6742. https://doi.org/10.3390/molecules15106733

Theakston, R.D.G., Laing, G.D., Fielding, C.M., Lascano, A.F., Touzet, J.M., Vallejo, F., et al., 1995, 'Treatment of snakebites by Bothrops species and Lachesis mula in Ecuador: Laboratory screening of candidates antivenoms', Transactions of Royal Society of Tropical Medicine and Hygiene 89(5), 550-554.

Uddin, G., Aliullah, W., Siddiqui, B.S., Alam, M., Sadat, A., Ahmad, A. \& Khan, A.U. 2011, 'Chemical constituents and phytotoxicity of solvent extracted fractions of stem bark of Grewia optiva Drummond ex Burret', Middle-East Journal of Scientific Research 8(1), 85-91.

Uys, A.C., Malan, S.F., VanDyck, S. \& Van Zyl, R.L., 2002, 'Antimalarial compounds from parinari capensis', Bioorganic Medicinal Cheministry Letter 12, 2167.
Vyas, N. \& Argal, A., 2014, 'Isolation and characterization of oleanolic acid from roots of Lantana camara', Asian Journal of Pharmaceutical and Clinical Research 7(suppl. 2), 189-191.

Yusuf, A.J., Abdullahi, M.I., Musa, A.M., Haruna, A.K., Mzozoyana, V. \& Abubakar, H., 2019a, 'Bioactive (+)-Catechin-3'-O-rhamnopyranoside from Neocarya macrophylla (Sabine) Prance (Chrysobalanaceae)', Egyptian Journal of Basic and macrophylla (Sabine) Prance (Chrysobalanaceae)', Egyptian Journal of Basic and
Applied Sciences 6(1), 124-136. https://doi.org/10.1080/2314808X.2019.1673549

Yusuf, A.J., Abdullahi, M.I., Musa, A.M., Haruna, A.K., Mzozoyana, V. \& Abubakar, H., $2019 \mathrm{~b}$, 'Antisnake venom activity and isolation of quercetin from the leaf of Neocarya macrophylla (Sabine) Prance ex F. White (Malpighiales: Chrysobalanaceae)', Brazilian Journal of Biological Sciences 6(13), 381-389.

Yusuf, P.O., Mamman, M., Ajagun, E., Suleiman, M.M., Kawu, M.U., Shittu, M. Isa, H.I., Tauheed, M. \& Yusuf, A., 2015, 'Snakes responsible for bites in north-eastern Nigeria - A hospital based survey', Journal of Environmental Science, Toxicology and Food Technology 9(9), 118-121. 